Thirteminth Scientifio Meetria-Sixth Scottish Meeting

Department of Physiology, University College, Dundee, MAY 29TH, 1943

\title{
EFFEGT OF PROGESSING AND HANDLING ON THE COMPOSITION, VITAMIN CONTENT, KEEPING QUALITY AND CULINARY PROPERTIES OF FISH
}

\author{
Chairman, Professor H. DRYerre
}

\section{The Effect of Preservation Processes on the Vitamin Content of Fish}

\section{Dr. J. A. Lovern (Torry Research Station (Department of Scientific and Industrial Research), Aberdeen)}

There are so many lacunae in our knowledge of the effect of the various methods of preservation on the vitamin content of fish, that the present paper can only be of a provisional and somewhat scrappy nature. I propose to deal with such evidence as there is on this subject under subheadings, according to the processes employed. Particulars as to the amounts of vitamins $A, B_{1}, B_{6}, C, D$, riboflavin and nicotinic acid present in fish can be found in a recent paper (Lovern, 1943), and are summarized in Table 1, in which average values are given, without regard to variation and range.

TABLE 1

Approximate Average Vitamin Contents of Fish and Fish Products

\begin{tabular}{|c|c|c|c|c|c|c|}
\hline Product & $\begin{array}{l}\text { Vitamin } \\
\text { A } \\
\text { I.U. per } \\
100 \mathrm{~g} .\end{array}$ & $\begin{array}{l}\text { Vitamin } \\
\text { B }_{1} \\
\text { I.U. per } \\
100 \mathrm{~g} \text {. }\end{array}$ & $\begin{array}{l}\text { Ribo- } \\
\text { flavin } \\
\mu \mathrm{g} . \text { per } \\
100 \mathrm{~g} .\end{array}$ & $\begin{array}{l}\text { Nicotinic } \\
\text { acid } \\
\text { mg. per } \\
\text { lo0 g. }\end{array}$ & $\begin{array}{l}\text { Vitamin } \\
\mathrm{C} \\
\text { mg. por } \\
100 \mathrm{~g} .\end{array}$ & $\begin{array}{l}\text { Vitamin } \\
\text { D } \\
\text { I.U. per } \\
\text { l00 g. }\end{array}$ \\
\hline $\begin{array}{l}\text { White fish flesh. } \\
\text { Fatty fish flesh . } \\
\text { Fish roe.. } \\
\text { Fish milt. }\end{array}$ & $\begin{array}{c}50 \\
200^{*} \\
? \\
?\end{array}$ & $\begin{array}{r}30 \\
30 \dagger \\
500 \dagger \\
60 \dagger\end{array}$ & $\begin{array}{c}200 \\
300 \\
1000 \ddagger \\
500\end{array}$ & $\begin{array}{l}3 \\
3 \S \\
? \\
?\end{array}$ & $\begin{array}{r}5 \\
5 \\
\mathbf{3 0} \\
\mathbf{5}\end{array}$ & $\begin{array}{l}\text { Nil } \\
1000^{*} \\
? \\
?\end{array}$ \\
\hline
\end{tabular}

* Except freshwater eel, where the value is about 4000 .

$\dagger$ " herring, where the value is about 10 .

$\ddagger "$ " " " " " 400 .

Freezing and Cold Storage. Practically nothing appears to have been published on the vitamin losses, if any, occurring during the freezing and cold storage of fish. Unpublished work by the writer on the cold storage of fish livers indicated that there was no appreciable loss of vitamin A over periods of many months, even at relatively high temperatures $\left(-10^{\circ}\right.$ C.) at which lipolysis was able to proceed. Fresh and frozen oysters contain about the same amount of vitamin A, 200 to 300 I.U. per $100 \mathrm{~g}$. (Booher, Hartzler and Hewston, 1942). 
The position with regard to vitamin $B_{1}$ is of interest in view of the recently acquired knowledge that raw fish contains a heat labile substance, possibly an enzyme, capable of destroying this vitamin (György, 1942). During the freezing process a certain amount of denaturation and cell disruption occurs and one might expect that destruction of vitamin $B_{1}$ would take place. The data of Pyke and Wright (1941), on the other hand, suggest that this is not the case, as they found about 80 I.U. per $100 \mathrm{~g}$. of vitamin $B_{1}$ in the flesh of a cold stored salmon. This is higher than the average content for most species, about 30 I.U. per 100 g., and considerably higher than what the same authors found for canned salmon, about $10 \mathrm{I} . \mathrm{U}$. per $100 \mathrm{~g}$.

In the same paper, Pyke and Wright (1941) reported that chilled salmon contained $9 \mathrm{mg}$. per $100 \mathrm{~g}$. of vitamin $\mathrm{C}$, which is of the same order as the vitamin $\mathrm{C}$ content of the flesh of many species of fish. The very high value of 89.9 to $215.6 \mathrm{mg}$. per $100 \mathrm{~g}$. reported for salmon by Fomin, Romanjuk and Chvoinitzka (1937) requires confirmation, as it is so much in excess of that found for other species.

Nothing appears to be known concerning the other vitamins. On general grounds, lack of drastic treatment such as heat and the general retardation of chemical reactions by low temperatures, one would expect almost complete stability. One potential source of loss of water soluble vitamins in frozen fish is in the "drip" which runs away when the fish are thawed again, but no experiment appears to have been made on this subject.

Smoking. In practice, smoking of fish is always accompanied by a certain amount of drying and salting, so that it is the combined effect of these treatments as, for instance, in kippering, which must be considered. Lunde (Lunde, 1937; Lunde, Aschehoug and Kringstad, 1937) studied the effect of this process on the vitamin A and D content of brisling and sild, small sprats and herring, as prepared for subsequent canning, and of herring fillets which were ultimately made into canned kippers. $\mathrm{He}$ found that the smaller fish, which were smoked whole, lost no vitamin A or vitamin $D$ in the process, but herring fillets showed a very small loss of vitamin A without loss of vitamin D. It may be noted that herring vary enormously in their content of both vitamins and Lunde himself pointed out that the estimation of the small amounts of vitamin A present is not very accurate.

Some isolated results by Pyke (1939) for haddock and herring suggest that vitamin $B_{1}$ is destroyed when fish are smoked, although it should be noted that his values for fresh haddock, 3 I.U. per 100 g., and herring, 2 I.U. per 100 g., are only about one-tenth of those of other workers. Nothing seems to have been reported as to the effect of smoking on vitamin $\mathrm{C}$ in fish. From some results of Lunde (1939), in which he found $300 \mu \mathrm{g}$. of riboflavin per $100 \mathrm{~g}$. of canned kippers, it appears that this vitamin must be practically stable to smoking, since the range of values reported for fresh herring flesh is 104 to $418 \mu \mathrm{g}$. per $100 \mathrm{~g}$. (Fixsen and Roscoe, 1940). The flesh of bloaters has also been reported to contain $260 \mu \mathrm{g}$. per $100 \mathrm{~g}$. Nicotinic acid has been estimated in both fresh herring flesh and preserved kippers by McVicar and Berryman (1942), and there is no evidence of any destruction, both foods containing about $3.5 \mathrm{mg}$. per $100 \mathrm{~g}$. Similar results were reported by Kringstad and Thoresen (1940).

voL. 2, 1944] 
Lunde (1938) has shown that vitamin $B_{6}$ is present in smoked fish, such as kippers, sild and brisling, although data are lacking from which one could estimate whether or not partial destruction occurred during the smoking process.

Salting and Drying. Fish and fish products are, of course, also preserved by salting, or salting and drying, without being smoked, e.g., salt herring and dry-salted cod. Practically no data seem to be available as to the effect of such processes on the vitamins of the fish, although there are isolated determinations of particular vitamins in certain products of this type. Thus, Aschehoug, Kringstad and Lunde (1939) found 1120 I.U. of vitamin D per $100 \mathrm{~g}$. in salted red char, Salmo alpinus, a variety of salmon, a figure which, by comparison with those obtained for other species of salmon and other fatty fish, suggests that little or no destruction could have occurred. Salted herring roe has been reported to contain 500 I.U. of vitamin A per $100 \mathrm{~g}$. (Leong, 1939), but data are lacking for fresh herring roe.

The new process of dehydration involves, of course, far more complete desiccation than the drying associated with salting and smoking. The effect of this process on the vitamins in fish has so far not been investigated, nor the effect of subsequent storage of the dried material. Vitamin $\mathrm{B}_{1}$ is one constituent deserving of particular attention in this respect, in so far as the fish are first minced in the raw condition, when the substance capable of destroying vitamin $B_{1}$ may become active. Apart from vitamin $D$ in fatty fish, however, fish flesh is not a rich source of any vitamin, as compared with certain other foodstuffs, so that the problem of the stability of the vitamins in dehydrated fish is not so important as it is in such products as dried milk and vegetables. By analogy with these other products, one would not expect extensive destruction during the dehydration process. Any destruction on storage in air would probably be a matter of oxidation and affect principally the easily oxidized vitamins such as vitamins $A$ and $C$. Gas packing should prevent this type of loss, if it is of sufficient importance.

Canning. There are far more data on the effect of canning on the vitamin content of fish and fish products than for other processes, largely because of the work of Lunde and his colleagues at the Research Laboratory of the Norwegian Canning Industry. In an early paper Lunde (1937) reported that when smoked fish, such as brisling and sild, were canned in olive oil, there was no loss of vitamin A, and that the canned product could be stored for years without loss of this vitamin. When, however, similar material, e.g., kippers, was canned in the dry state, there was an appreciable loss of vitamin A. His actual figures showed a range of values for the canned article of 50 to $60 \mathrm{I}$.U. per $100 \mathrm{~g}$. as against a range of 20 to $380 \mathrm{I} . \mathrm{U}$. per $100 \mathrm{~g}$. for fillets from a similar class of fresh fish. It should be noted that in view of experimental difficulties in determining vitamin $A$ at low concentrations, as well as of variation from fish to fish, many determinations are needed before conclusions can be reached as to the stability or otherwise of the vitamin when the data, as in this case, refer to different batches of fish. In a later publication Lunde (1939) reported that a long series of tests showed that vitamin A in fish flesh is completely stable to canning when all air in the can is removed. This, of course, is the case when the can is filled with olive oil. Bacharaoh, 
Cruickshank, Henry, Kon, Lovern, Moore and Morton (1942) examined a few samples of canned herrings, some with tomato sauce and some without, and found that the vitamin A content, estimated spectroscopically, was always at the lower end of the range observed for fresh herring. These authors remarked that the number of samples was too small for reliable deductions to be made. Oil from canned salmon, tested biologically, has been reported (Devaney and Putney, 1935) to contain 25 to 800 I.U. of vitamin A per 100 g., while similar tests by other workers on oil from 2 specimens of fresh salmon showed values of 4400 and 52,500 I.U. per $100 \mathrm{~g}$. By chemical methods Pyke and Wright (1941) were unable to detect any vitamin $A$ in either fresh or canned salmon. As with the herring, far more extensive series of tests, or alternatively tests of specially chosen material, are needed before any reliable conclusions can be drawn from these data.

Pyke and Wright (1941) also tested 12 samples of canned salmon for vitamin $B_{1}$ and found values ranging from 8 to $15 \mathrm{I}$.U. per $100 \mathrm{~g}$. For one sample of chilled salmon they got values of 76 and 86 I.U. per $100 \mathrm{~g}$. for two different cuts. This suggests considerable destruction on canning, although further samples of fresh salmon require to be examined. Baker and Wright (1935) reported 30 I.U. per $100 \mathrm{~g}$. in canned sardines, a figure which compares favourably with the value reported for fresh herring and brisling by Lunde (1939). Fish roe, other than the roe of clupeoids, is a much richer source or vitamin $B_{1}$ than fish flesh, and Lunde (1939) states that when fish roe is canned, 80 per cent. of vitamin $B_{1}$ remains intact, although a considerable proportion of it passes into the free liquor in the can.

Lunde (1938) reported that riboflavin in fish products was stable to canning. He found $300 \mu \mathrm{g}$. per $100 \mathrm{~g}$. in canned kippers (Lunde, 1939), which compares with a range of 104 to $418 \mu \mathrm{g}$. per $100 \mathrm{~g}$. reported for fresh herring (Fixsen and Roscoe, 1940).

Nicotinic acid is apparently quite stable in canning. Fresh cod has been reported to contain 1.7 to $3.0 \mathrm{mg}$. per $100 \mathrm{~g}$. (Bacharach, 1941), and canned cod $1.7 \mathrm{mg}$. per $100 \mathrm{~g}$. (McVicar and Berryman, 1942). Fresh herring has a value ranging from 2.9 to $4.0 \mathrm{mg}$. per $100 \mathrm{~g}$. (Kringstad and Thoresen, 1940; Bacharach, 1941), and canned kippers $2 \cdot 8$ to $3 \cdot 4 \mathrm{mg}$. per 100 g. (McVicar and Berryman, 1942; Kringstad and Thoresen, 1940).

Precise figures seem to be lacking for vitamin $B_{6}$, but Lunde (1939) found large quantities in canned cod roe and stated that it is stable to canning.

Data are also lacking concerning the effect of canning on vitamin $\mathrm{C}$ in fish. Fish roe is the richest fish source of this vitamin but fish flesh is a poor source, comparable with lean meat. Pyke and Wright (1941) found $9 \mathrm{mg}$. per $100 \mathrm{~g}$. in the flesh of chilled salmon and none in canned salmon. The high value previously reported for fresh salmon (Fomin, Romanjuk and Chvoinitzka, 1937) of $89 \cdot 9$ to $215 \cdot 6 \mathrm{mg}$. per $100 \mathrm{~g}$. requires confirmation.

According to the work of Lunde $(1937,1939)$ and of Ascheboug, Kringstad and Lunde (1939), vitamin D in such products as herrings, brisling and sild is completely stable both to the canning operation itself and to subsequent storage of the canned article for several years. On the other hand, Bacharach, Cruickshank, Henry, Kon, Lovern, Moore and voL. 2, 1944] 
Morton (1942) observed appreciably lower values for the vitamin $\boldsymbol{D}$ content of canned herring than for fresh herring. In spite of the observed considerable variations from sample to sample, these lower values were so consistent that the authors considered them as definitely suggesting that four-fifths of the vitamin $D$ was lost on canning. This huge discrepancy between the results of the Norwegian and the British groups of workers indicates the need for more work on this subject. Canned salmon has been reported to contain from 200 to 800 I.U. of vitamin D per $100 \mathrm{~g}$. (Cunningham, 1937), varying with the species, and the oil from fresh salmon has been stated to contain 9500 to 20,000 I.U. per 100 g. (Fixsen and Roscoe, 1940). Assuming 10 per cent. of oil in the flesh, this would give 950 to 2000 I.U. per $100 \mathrm{~g}$. for the flesh, which again suggests extensive destruction on canning.

This paper is published with the permission of the Department of Scientific and Industrial Research.

\section{REFERENCES}

Aschehoug, V., Kringstad, H. and Lunde, G. (1939). J. Soc. chem. Ind., Lond., 58,220 .

Bacharach, A. L. (1941). Nutr.. Abstr. Rev. 10, 459.

Bacharach, A. L., Cruickshank, E. M., Henry, K. M., Kon. S. K., Lovern, J. A., Moore, T. and Morton, R.A. (1942). Brit. med. J. ii, 691.

Baker, A. Z, and Wright, M. D. (1935). Biochem. J. 29, 1802.

Booher, L. E., Hartzler, E. R. and Hewston, E. M. (1942). Circ. U.S. Dep. Agric. no. 638.

Cunningham, M. M. (1937). N.Z. J. Sci. Tech. 17, 563.

Devaney, G. M. and Putney, L. K. (1935). J. Home Econ. 27, 658.

Fixsen, M. A. B. and Roscoe, M. H. (1940). Nutr. Abstr. Rev. 9, 824.

Fomin, S. V., Romanjuk, N. M. and Chvoinitzka, M. A. (1937). Ukr. biokhem. Zh. 10, 365 .

Gyorgy, P. (1942). Ann. Rev. Biochem. 11, 309.

Kringstad, H. and Thoresen, F. (1940). Tidsskr. Hermetikin lustr. 26, 113.

Leong, P. C. (1939). J. Malaya Br. Brit. med. Ass. 2, 219.

Lovern, J. A. (1943), Chem. and Ind. 62, 328.

Lunde, G. (1937). Fischwaren Feinkost-Industr. 2, 111.

Lunde, G. (1938). Nord. med. Tidskr. 15, 444.

Lunde, G. (1939). Angew. Chem.52, 521.

Lunde, G., Aschehoug, V. and Kringstad, H. (1937). Industr. Engng Chem. 29, 1171 .

McVicar, R. W. and Berryman, G. H. (1942). J. Nutrit. 24, 235.

Morgan, A. F., Kimmel, L. and Davison, H. G. (1939). Food Res. 4, 145.

Pyke, M. (1939). J. Soc. chem. Ind., Lond., 58, 338.

Pyke, M. and Wright, M. D. (1941). Nature, Lond., 147, 267. 


\title{
The Effect of Smoke Curing and Salt Curing on the Composition, Keeping Quality and Culinary Properties of Fish
}

\author{
Dr. J. M. Shewan (Torry Research Station (Department of Scientific \\ and Industrial Research), Aberdeen)
}

The curing of fish by smoke or salt, both of which are ancient practices, is still much in use today. In Scotland, just before the war, the production of smoked white fish, mainly haddocks, amounted to about 30 per cent. of the total landings of these species and about 20 per cent. of the herring catch was kippered. Little of the white fish landed here is now salt cured, perhaps only 10 per cent. of the total landed, but considerable quantities are annually produced in Canada, Newfoundland, Iceland, Norway and elsewhere. In the case of herring, on the other hand, 47 per cent. of the total British catch in 1938 was salted, almost exclusively for export (Fishery Board for Scotland, 1939).

\section{The Process}

\section{Smoke Curing}

Briefly, the smoke curing process is as follows: The eviscerated fish, split, white fish ventrally and herrings dorsally, or fillets of fish, are immersed for some 10 to 20 minutes in strong brine 70 to 80 per cent. saturated, which may or may not contain dye. The fish are then hooked vertically on tenters, or laid over sticks in the case of fillets, in order to drain off surplus brine and to permit some surface drying. Finally, the fish are exposed to the action of warm wood and/or peat smoke until a desired "point of finish" has been reached. In practice every step in this procedure is subject to variation. Thus, the duration of brining may be increased for very large, thick fish or for cures destined for foreign markets demanding a highly salted product.

Various "points of finish" correspond with a variety of cures ranging in the haddock for example, from "pales" or light cures to "finnans" or heavy cures. Naturally the extent of curing, that is the extent of drying and impregnation with smoke, is proportional to the time spent in the smoke kiln. In well cured "pale" and "finnan" haddocks the losses of weight due to drying are respectively about 8 to 12 and 15 to 20 per cent. These cures range from light to golden brown in colour, from mild to strongly smoky in odour and flavour, and have all translucent, resilient flesh, overlaid by a glossy bright, shining pellicle. This pellicle is the result of drying the superficial sticky layer of protein peptized by the action of the brine, and probably also of the deposition on the surface of resinous condensation products from the smoke. Apart from its effect upon appearance, the pellicle, once formed, is said to prevent excessive drying during smoking. In the production of well cured kippers, herrings lose 15 to 25 per cent. in weight. Such cures have a brown colour, good smoky odour and flavour, and a pleasant soft texture attributable to the oil present, which also confers a shining appearance on the fish.

vor. 2,1944$]$ 
The salt content of smoke cured fish generally lies between 2 and 3 per cent., quantities in excess of this being usually regarded as unpalatable. The preservative effect of salt in such amount is probably small, so that apart from its role in pellicle formation, salt should be considered mainly as providing a condiment (Griffiths and Lemon, 1934).

In "cold smoking," the type usually employed in this country, the temperature falls within the range $25^{\circ}$ to $32^{\circ} \mathrm{C}$. ( $77^{\circ}$ to $89 \cdot 6^{\circ} \mathrm{F}$.). "Hot smoking," a procedure followed on the continent, involves much higher temperatures, $100^{\circ}$ to $120^{\circ} \mathrm{C}$. $\left(212^{\circ}\right.$ to $248^{\circ} \mathrm{F}$.), the fish being partially cooked in the kiln (Le Gall, 1938).

As might be expected, the smoke constituents, and hence the flavour and appearance of the cure, vary with the type of wood used and the condition of combustion. It has long been considered in the trade that, of the hard woods, oak produces the best colour and flavour and that soft resinous woods result in rather acid, acrid flavours and odours. Apart from these empirical results little is known about the constituents responsible for the flavours or aromas in cured fish, although, with the recent publication by Pettet and Lane (1940) on the composition of wood smoke, some progress has been made in this direction.

Using oak wood, these authors found, and in some instances estimated, the following compounds in the smoke: aldehydes and ketones (formaldehyde, acetaldehyde, furfuraldehyde, diacetyl, acetone), alcohols (methyl and ethyl), acids (formic and acetic), phenols, tars and water. The phenols and the aliphatic acids, especially the latter, were found to possess acrid, acid tastes and odours, which no doubt would be transferred to the fish. It was also found that the relative proportions of these constituents in the smoke could be altered by changing the conditions of combustion, by variation in the supply of air.

It has subsequently been reported that condensed ring compounds, many of which are known to be carcinogenic, are not present in oak wood tar, and that biological tests on mice and rats have confirmed this finding (British Empire Cancer Campaign, 1941).

Little is known yet of the extent to which fish absorb the various constituents of smoke during curing. At the Torry Research Station the Buchanan and Schryver (1909) method of estimating formaldehyde in flesh has been applied to a few samples of commercially cured "finnans" and kippers. The contents of formaldehyde found were, respectively, 90 to 200 p.p.m. and 33 to 95 p.p.m. Callow (1927), using the same method, has reported values ranging from 250 to 1000 p.p.m. for kippers. It is of interest in this connexion that positive reactions are given by fresh, uncured fish representing, for example, the presence of 5 to 40 p.p.m. in haddocks iced for 6 days. Callow (1927) reports 0.5 to 3 p.p.m. in fresh herring.

\section{The Chemical Composition of Smoked Fish}

It will be obvious from what has been said above, that smoked fish will differ in their composition from fresh fish, by containing, in addition to the materials absorbed from the smoke, more salt and less water. It will also be obvious that, given the same smoking conditions, the 
composition of the smoked fish will depend largely on that of the fish from which they are made.

In white fish, haddocks in particular, the composition in terms of fat, protein and water, is known to remain fairly constant throughout the year (Crooks and Ritchie, 1939) with the result that well cured "pales" and "finnans" also show a fairly constant chemical composition. Some typical examples are given in Table 1.

Herring, on the other hand, show wide seasonal variations. Thus Lovern and Wood (1937) in a detailed analysis of the composition of herring, mainly from Scottish waters, found that, while the "protein" (fat free solids) remained almost constant throughout the year, 84 per cent. of the values falling between 18 and 20.5 per cent., the fat showed wide variations, from 2 to 22 per cent. This variation, it was found, was due mainly to feeding and the influence of the reproductive cycle, spring caught "spent" fish having the lowest fat contents.

As might be expected, these changes in the composition of the herring are reproduced in the kipper, affecting in turn its palatability, texture and nutritive value. Table $l$ shows the average composition of herring

\section{TABLE I} Chemical Composition of Fresh and Smoked Fish Expressed as
Percentage

\begin{tabular}{|c|c|c|c|c|c|}
\hline Kind of fish & Water & $\begin{array}{l}\text { Total } \\
\text { solids }\end{array}$ & $\begin{array}{l}\text { Protein } \\
(\mathrm{N} \times 6 \cdot 25)\end{array}$ & Fat & $\begin{array}{l}\text { Sodium } \\
\text { chloride }\end{array}$ \\
\hline Haddock & & & & & \\
\hline $\begin{array}{l}\text { Fresh } \% \text { "Pales" (well cured, } \\
11 \text { to } 13 \text { per cent. }\end{array}$ & $79 \cdot 1$ to $84 \cdot 1$ & $15 \cdot 9$ to $20 \cdot 9 \mid$ & 14.6 to 20.3 & $0 \cdot 1$ to $0 \cdot 6$ & $0 \cdot 21$ \\
\hline $\begin{array}{c}\text { loss in weight) } \\
\text { "Finnans" (well cured, }\end{array}$ & $78 \cdot 0$ & $22 \cdot 0$ & - & - & 3.0 to 4.0 \\
\hline $\begin{array}{l}24 \text { to } 26 \text { per cent. } \\
\text { loss in weight) }\end{array}$ & $73 \cdot 5$ & $26 \cdot 5$ & - & - & 3.5 to 4.5 \\
\hline $\begin{array}{r}\text { Smoked } \quad \text { (Plimmer, } \\
1921)\end{array}$ & $75 \cdot 3$ & $24 \cdot 7$ & $19 \cdot 6$ & $0 \cdot 3$ & 4.5 (ash) \\
\hline Smoked (Chatfield and & & & & & \\
\hline Adams, 1940) $\quad$. & $72 \cdot 6$ & $27 \cdot 4$ & $23 \cdot 2$ & 0.4 & $3 \cdot 1(\mathrm{ash})$ \\
\hline $\begin{array}{l}\text { Herring } \\
\text { Fresh (Lovern and }\end{array}$ & & & & & \\
\hline $\begin{array}{c}\text { Fresh (Lovern } \\
\text { Wood, 1937) }\end{array}$ & 62.4 to $73 \cdot 6$ & $\left|\begin{array}{c}16 \cdot 1 \text { to } 20 \cdot 2 \\
\text { (fat free) }\end{array}\right|$ & - & $6 \cdot 2$ to $21 \cdot 6$ & 0.2 to 0.3 \\
\hline $\begin{array}{c}\text { Kipper (Lovern and } \\
\text { Reay, 1938) }\end{array}$ & $47 \cdot 4$ to $63 \cdot 4$ & $\mid \begin{array}{c}21 \cdot 7 \text { to } 31 \cdot 5 \\
\text { (fat free) }\end{array}$ & - & $8 \cdot 1$ to $28 \cdot 1$ & $2 \cdot 0$ to $3 \cdot 0$ \\
\hline $\begin{array}{c}\text { Kipper (Plimmer, } \\
1921 \text { ) }\end{array}$ & $62 \cdot 5$ & $37 \cdot 5$ & $18 \cdot 8$ & $14 \cdot 9$ & 4.5 (ash) \\
\hline $\begin{array}{l}\text { Kipper (Chatfield and } \\
\text { Adams, 1940) }\end{array}$ & $61 \cdot 0$ & $39 \cdot 0$ & $22 \cdot 2$ & $12 \cdot 9$ & 4.0 (ash) \\
\hline
\end{tabular}

and of kippers made from them. For comparison the figures for the composition of kippers given by Plimmer (1921) and Chatfield and Adams (1940) are included in the table.

voL. 2, 1944] 


\section{Keeping Quality of Smoked Fish}

Smoke curing was doubtless resorted to in the first instance as a means of preservation in the days before the use of artificial ice and cold storage but, although it affords preservation for only a relatively short time, it still holds its own today because of the peculiar palatability of the cures. Some very light cures, that keep scarcely longer than uncured fish, are made specially for their attractive flavour.

The preservative effect of the smoking process is considered to be due equally to drying and to the bactericidal properties of some of the smoke constituents. The keeping quality of smoked fish will of course also be affected by the freshness of the original fish. Experimental work in this and other countries shows that the original bacterial load is reduced by some 85 to 90 per cent. by heavy or "finnan" curing (Hess, 1929). The main chemical bactericidal effect is generally attributed to the combined action of formaldehyde and phenolic substances (Griffiths and Lemon, 1934; Stewart, unpublished; Metzner, 1933).

At the Torry Research Station it was found that "pale" cured fillets of whiting made commercially from reasonably fresh fish kept in condition almost as good as the original at $15^{\circ} \mathrm{C}$. $\left(59^{\circ} \mathrm{F}\right.$.) for 1 to $1 \frac{1}{2}$ days. After $2 \frac{1}{2}$ to 3 days, however, the fish became unpalatable to the consumers, accustomed as they were to a high grade article. For storage at $0^{\circ} \mathrm{C}$. $\left(32^{\circ} \mathrm{F}\right.$.) the corresponding figures were $2 \frac{1}{2}$ to 3 days and 6 to 7 days. Well cured commercial "finnans" and kippers kept in good condition at $15^{\circ} \mathrm{C}$. (59 $9^{\circ} \mathrm{F}$.) for 2 to 3 days, becoming unpalatable after 4 to 6 days. For storage at $0^{\circ} \mathrm{C}$. $\left(32^{\circ} \mathrm{F}\right.$.) the corresponding figures were 4 to 6 days and 15 to 20 days (Cutting, 1942).

For some considerable time now the dyeing of white fish and herrings before curing has been a practice in the trade, although much fish is still treated in the traditional way. Since dye, although imparting colour, has relatively little preservative action, it is necessary to cure dyed fish to the same extent as undyed fish, if the preservation and flavour that accompany normal colour production in the latter case are to be obtained.

\section{Culinary Properties of Smoked Fish}

Smoke curing alters the culinary properties in so far as the drying involved results in a less juicy flesh and tougher texture (Forbes, 1926). For this reason smoke cured white fish, particularly the heavier. "finnan" cures, are better steamed in casserole or stewed, than fried or grilled. In kippers the toughening effect is counteracted by the oil present and the texture is considerably softer. As a result, they are suited to all the methods of cooking mentioned.

\section{The Process}

\section{Salt Curing}

In comparison with smoke curing, salt curing is a long term method of preserving fish. With the rise of the steam fishing vessel, the introduction of refrigeration, and the development of rapid transport, the supply of fresh fish to all parts of this country has so greatly increased, that the consumption of salt fish has steadily declined until the taste for it has largely been lost. In consequence the greater part of the salt cures made here are exported. 
Two typical cures will be briefly considered, dried, salted white fish, such as cod, ling, haddock, and wet pickled herrings. The white fish after being split ventrally, the backbone being removed save for the tail portion, are laid in piles, salt being interspersed between the layers. The juices, withdrawn from the fish by the salt to form a pickle, are allowed to run away. Within 15 days, or a little more at ordinary temperatures, the salt has generally penetrated or "struck through" the flesh, saturating the remaining juices. The "green" cure obtained is said to be lying in "wet stack" and remains so, sometimes for a month or two, until the finishing process of drying is begun. In this, further moisture is extracted by exposing the fish hung singly on racks to the sun and wind, or to artificially heated air. In the latter case, the fish are often hung above coke fires. The fish, dried to various extents according to the requirements of various markets, are packed in cases or in bales for export.

In wet pickling herring, the fresh fish, after a preliminary treatment with a small quantity of salt which removes surface slime, facilitates handling, and begins the process of salting, are "gibbed," i.e., freed from gills and gut, the milt or roe being left in situ. The fish are then packed into barrels in a traditional manner, stlt being put between the tiers. In a day or two the fish shrink, when more fish at the same stage of cure are added to the barrel. After 8 to 10 days the "blood" pickle is run off at the bung hole, the barrel filled tightly with cured fish and the spaces then filled with "blood" pickle. Fresh brine is not used for this purpose, since it is said to promote rancidity, presumably because of the removal of natural anti-oxidants.

White fish fillets are sometimes "wet pickled" in barrels.

Many of the physical factors involved in the production of satisfactory cures have been investigated, and it has been shown that while dry salting may be considered as a mere diffusion of water out of, and brine into, the fish, following the van't Hoff diffusion law (Turpaev, 1926), the osmotio relationships in the pickling process are much more complex and obscure (Reay, 1936).

The chemical, bacteriological and enzymic changes involved in the ripening process by which the fish acquire their characteristic flavour and odour are still more obscure, although some progress has been made both here (Shewan, 1937, 1938) and in Russia (Buianovska, 1934; Messing, 1934; Aleev, Popova and Bereznoi, 1936) in determining whether the tissue enzymes or bacteria are involved. The evidence available so far seems to indicate that the bacteria, at any rate, play an essential role in the production of the authentic cured flavour.

\section{The Chemical Composition of Salt Fish}

Compared with fresh fish, salt fish differs chiefly in containing less water and more salt. Table 2 gives the composition, in terms of water, salt, and salt free total solids, roughly equivalent to the amount of protein, of some typical samples of salt cod. As is to be expected, dried salted cod contains the least water and the most salt free solid ("protein") and salt; pickled cod, on the other hand, contains most water and least "protein," and cod in "wet stack" resembles it in composition. vor $\{2,1944]$ 
TABLE 2

Chemmoal Composition of Fresh and Salted Cod Expressed as Percentage

\begin{tabular}{|c|c|c|c|c|c|}
\hline Kind of fish & $\begin{array}{c}\text { No. of } \\
\text { samples }\end{array}$ & Water & $\begin{array}{l}\text { Total } \\
\text { solids }\end{array}$ & $\begin{array}{c}\text { Salt free } \\
\text { solids } \\
\text { ("proteins") }\end{array}$ & $\begin{array}{l}\text { Sodium } \\
\text { chloride }\end{array}$ \\
\hline $\begin{array}{l}\text { Cod } \\
\text { Fresh } \\
\text { Salted } \\
\text { Pickled .. } \\
\text { In "wet stack" .. } \\
\text { Hard dried .. }\end{array}$ & $\begin{array}{l}9 \\
9 \\
6\end{array}$ & $\begin{array}{l}81 \cdot 0 \text { to } 84 \cdot 0 \\
\text { (Aver. } 82 \cdot 1 \text { ) } \\
\\
54 \cdot 0 \text { to } 60 \cdot 0 \\
\text { (Aver. 56.4) } \\
48 \cdot 0 \text { to } 58 \cdot 0 \\
\text { (Aver. } 54 \cdot 0 \text { ) } \\
20 \cdot 0 \text { to } 26 \cdot 5 \\
\text { (Aver. 22.9) }\end{array}$ & $\begin{array}{l}16 \cdot 0 \text { to } 19 \cdot 0 \\
\text { (Aver. } 17 \cdot 9 \text { ) } \\
40 \cdot 0 \text { to } 46 \cdot 0 \\
\text { (Aver. } 43 \cdot 6) \\
42 \cdot 0 \text { to } 52 \cdot 0 \\
\text { (Aver. } 46 \cdot 0) \\
73 \cdot 5 \text { to } 80 \cdot 0 \\
\text { (Aver. } 77 \cdot 0 \text { ) }\end{array}$ & $\begin{array}{l}15 \cdot 8 \text { to } 18 \cdot 8 \\
\text { (Aver. } 17 \cdot 6) \\
\\
18 \cdot 7 \text { to } 26 \cdot 7 \\
\text { (Aver. } 23 \cdot 7) \\
22 \cdot 7 \text { to } 33 \cdot 3 \\
\text { (Aver. } 26 \cdot 1) \\
42 \cdot 4 \text { to } 56 \cdot 0 \\
\text { (Aver. } 49 \cdot 3)\end{array}$ & $\begin{array}{l}0.18 \text { to } 0.23 \\
\text { (Aver. } 0 \cdot 21 \text { ) } \\
\\
18 \cdot 6 \text { to } 21 \cdot 3 \\
\text { (Aver. } 20 \cdot 0 \text { ) } \\
18 \cdot 7 \text { to } 21 \cdot 6 \\
\text { (Aver. } 19 \cdot 7 \text { ) } \\
24 \cdot 0 \text { to } 31 \cdot 6 \\
\text { (Aver. } 28 \cdot 0 \text { ) }\end{array}$ \\
\hline
\end{tabular}

The composition of three typical cures of salt herring, June (Castlebay) cured in saturated brine, and July (Fraserburgh) cured in brine of 75 to 80 per cent. saturation, and in saturated brine, respectively, is given in Table 3.

TABLE 3

Chemical Composition of Fresh and Cured Herring Expressed as Percentage

\begin{tabular}{|c|c|c|c|c|c|}
\hline Kind of fish & Water & $\begin{array}{l}\text { Total } \\
\text { solids }\end{array}$ & $\begin{array}{l}\text { Protiin } \\
(\mathrm{N} \times 6.25)\end{array}$ & Fat & $\begin{array}{l}\text { Sodium } \\
\text { chloride }\end{array}$ \\
\hline $\begin{array}{l}\text { Herring } \\
\text { Fresh } \\
\text { June, Castlebay } \ldots \\
\text { July, Fraserburgh } \ldots \\
\text { Salt } \\
\text { June, Castlebay, } 6 \text { days in } \\
\text { saturated brine } \ldots \\
\text { July, Fraserburgh, } 13 \text { days in } \\
75 \text { per cent. saturated brine } \\
\text { July, Fraserburgh, } 13 \text { days in } \\
\text { saturated brine } \ldots \\
\text { July, Fraserburgh, } 30 \text { days in } \\
75 \text { per cent. saturated brine } \\
\text { July, Fraserburgh, } 30 \text { days in } \\
\text { saturated brine } \ldots\end{array}$ & $\begin{array}{l}48 \cdot 6 \\
54 \cdot 0 \\
55 \cdot 1\end{array}$ & $\begin{array}{l}46 \cdot 0 \\
44 \cdot 9\end{array}$ & $\begin{array}{l}15 \cdot 3 \\
17 \cdot 1 \\
14 \cdot 1\end{array}$ & $\begin{array}{l}21 \cdot 5 \\
22 \cdot 2 \\
\\
18 \cdot 2\end{array}$ & $\begin{array}{r}0.27 \\
0.25 \\
17 \cdot 6 \\
10 \cdot 1 \\
9.1 \\
9 \cdot 6 \\
11.7\end{array}$ \\
\hline
\end{tabular}

In general, salt herrings contain less water and fat, but more total solids, protein, and salt than fresh herrings. Also the "hard" cure in saturated brine contains less water, but more salt and total solids than the lighter cure.

Comparing Tables 2 and 3 , it will be seen that salt herring have a much higher fat content and a correspondingly lower water content than pickled cod. Normally, herrings are salt cured only when the fat content is 
fairly high, and so the cures are never likely to show the wide variations found in kippers.

\section{Keeping Quality of Salt Fish}

Dried, salted cod and wet pickled cod will keep in excellent condition at ordinary temperatures, $10^{\circ}$ to $15^{\circ} \mathrm{C}$. or $50^{\circ}$ to $59^{\circ} \mathrm{F}$., for 4 to 6 months. On the other hand, salted cod in "wet stack" keep in good condition for only about 2 to 3 months, after which "pink" spoilage sets in. This results from the growth and activity of aerobic halophilic bacteria, that cover the flesh with a pink slime, and, by attacking the proteins, soften the fish and cause it to give off offensive odours (Klebahn, 1918; Harrison and Kennedy, 1922; Gibbons, 1936; Shewan, 1936, 1938). At chill temperatures, $0^{\circ}$ to $4^{\circ} \mathrm{C}$. or $32^{\circ}$ to $39 \cdot 2^{\circ} \mathrm{F}$, all three cures keep in excellent condition for about a year.

Heavily cured herrings, in brine of 90 to 100 per cent. saturation, keep in good edible condition for 3 to 4 months at room temperature, $15^{\circ} \mathrm{C}$. or $59^{\circ} \mathrm{F}$., becoming inedible after a few more months. At $-3^{\circ} \mathrm{C}$., $26.6^{\circ} \mathrm{F}$, they keep in excellent condition for at least a year. Lighter cures, in brine of 75 to 80 per cent. saturation, quickly spoil at $15^{\circ} \mathrm{C}$. or $59^{\circ} \mathrm{F}$. after a month, but at $-3^{\circ} \mathrm{C}$., $26 \cdot 6^{\circ} \mathrm{F}$., they are in good condition even after a year.

\section{Culinary Properties of Salt Fish}

Salt curing produces a much more drastic change in the appearance, texture, flavour and odour of the fish than smoke curing. The flesh is shrunken, tough and often dry, and the "cured," "salt fishy" odours and flavours are now disliked by many people. Salt fish cannot be used directly for cooking. Herrings, it is true, are sometimes eaten raw, as is the normal practice on the Continent, but preliminary desalting is necessary before cooking. Desalting is usually done by placing the fish overnight in water "to cover," large fish, like cod, being cut into pieces, after which the fish may be boiled and served with white sauce and seasoning, or made into fish cakes or fish pie with potato. Such desalting, while normally preserving some of the odours and flavours desired by the connoisseur, usually gives a dish too salty for most palates, except when the fish is well diluted by potatoes as in fish pies or cakes. On the other hand, if the desalting time is sufficiently prolonged to reduce the salt content to 2.5 per cent., a generally palatable level, the resulting product after steaming or frying is rather insipid, tasteless and woolly or fibrous in texture. Tolerable fish cakes or pies can, however, be made. Even when smoked, as has recently been shown with desalted "wetstack" cod, the product, although much improved and more widely acceptable, cannot be considered to be comparable in flavour or texture to a smoke cured fresh fish.

In general, the desalting time is proportional to the size of the fish, small fish requiring less time than larger fish. Further, dried salted fish are desalted in about one-half to one-third of the time required by either "pickled" or "wet stack" fish of the same size.

Desalting, of course, alters the composition of the fish, owing to the influx of water and the reduction of the salt content. Some typical analyses for well desalted cod, "dried," "wet stack" and "pickled," are given in Table 4. It will be noted that the amount of water present in voL. 2, 1944] 
TABLE 4

Chemical Composition of Desalted Cod Expressed as Percentage

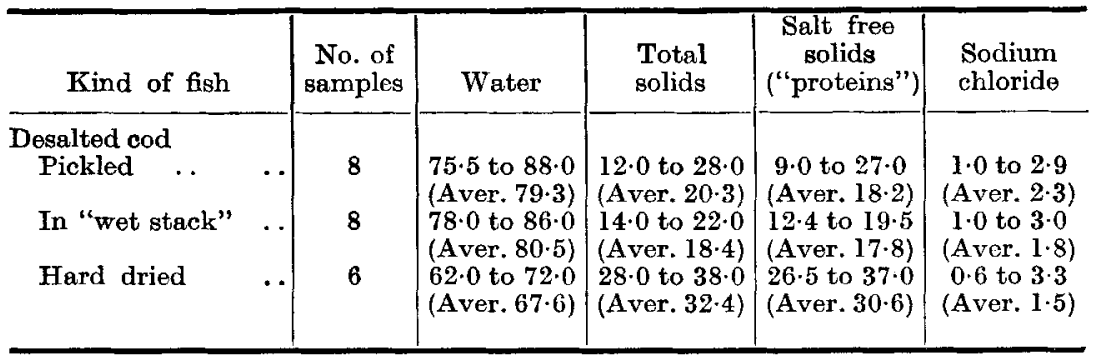

the desalted "wet stack" and "pickled" samples is equivalent roughly to that present in fresh cod. In dried fish, on the other hand, much less water is picked up than by the other two cures, even although the final salt content in all three groups is approximately the same.

This paper, largely based on work carried out as part of the programme of the Food Investigation Board, is published by permission of the Department of Scientific and Industrial Research.

\section{References}

Aleev, B. C., Popova, N. E. and Bereznoi, N. D. (1936). Vop. Pitan. 5, 17.

British Empire Cancer Campaign (1941). Rep. Brit. Emp, Cancer Campgn, 18, 113. Buchanan, G. S. and Schryver. S. B. (1909). Rep. loc. Govt Bd publ. Hlth, no. 9, New Series, no. 12.

Buianovska, I. S. (1934). Vop. Pitan. 3, 110.

Callow, E. H. (1927). Analyst, 52, 391.

Chatfield, C. and Adams, G. (1940). Circ. U.S. Dep. Agric. no. 549.

Crooks, G. C. and Ritchie, W. S. (1939). Food Res. 4, 159.

Cutting, C. L. (1942). Food Manuf. 17, 219.

Fishery Board for Scotland (1939). Rep. Fish. Bd Scot. 1938.

Forbes, J. C. (1926). Trans, roy. Soc. Can. 3rd Ser, 20, 145.

Gibbons, N. E. (1936). J. Biol. Bd Can. 3, 69.

Griffiths, F. P. and Lemon, J. M. (1934). Invest, Rep. U.S. Bur. Fish. no. 20.

Harrison, F. C. and Kennedy, M. E. (1922). Trans. roy. Soc. Can. 3rd Ser. 16, 105. Hess, E. (1929). Contr. Canad. Biol. Fish. N.S. 4, 29.

Klebahn, H. (1918). Jb, hamburg. wiss. Anst. 36, Beiheft 2.

Le Gall, J. (1938). Rev. Trav. Off. Pêches marit. 11, 59.

Lovern, J. A. and Wood, H. (1937). J. Mar. biol. Ass. U.K. 22, 281.

Lovern, J. A. and Reay, G. A. (1938). Rep. Food Invest. Bd, Lond., 102.

Messing, V. A. (1934). Vop. Pitan. 3, 113.

Metzner, H. (1933). Dtsch. FischRdsch. 23, 495.

Pettet, A. E. J. and Lane, F. G. (1940). J. Soc. chem. Ind., Lond., 59, 114.

Plimmer, R. H. A. (1921). Analyses and Energy Values of Foods. London: H.M.S.O.

Reay, G. A. (1936). J. Soc. chem. Ind., Lond., 55, 309.

Shewan, J. M. (1936). Rep. Food Invest. Bd, Lond., 108.

Shewan, J. M. (1937). Rep. Food Invest. Bd, Lond., 84.

Shewan, J. M. (1938). Rep. Food Invest. Bd, Lond., 113; 115.

Stewart, M. M. Unpublished results.

Turpaev, M. I. (1926). Theory and Practice of Salting Herring in Astrakhan. Leningrad (in Russian). 


\title{
The Effect of Refrigeration and Dehydration on the Composition, Keeping Quality and Culinary Properties of Fish
}

\author{
Dr. C. L. Cutting (Torry Research Station (Department of Scientific \\ and Industrial Research), Aberdeen)
}

\section{Introduction}

In contrast to salt curing, the traditional long term method of preserving fish (Shewan, 1944), modern methods, refrigeration, dehydration and canning, in general bring micro-organisms and enzymes much more effectively under control, thus avoiding or greatly retarding the development of undesirable flavours. At the same time this is accomplished without inducing physical and chemical changes of an undesirable nature.

\section{Stowage in Ice}

\section{Refrigeration}

Although it affords a very limited term of preservation as compared with freezing and cold storage, stowage in ice is at present of the highest importance in the great trawl and line fishery for white fish, i.e., demersal or bottom feeding species. By this means of preservation and the use of speedy steam fishing vessels it has been possible to extend fishing operations well into the Arctic and the Tropics, involving at times voyages of three weeks' duration or even more. The use of ice is exceptional with pelagic fishes, that is surface feeding migratory fatty fish such as herring, caught mainly by drift net, because the fishery lies close round our shores and voyages are typically of only overnight duration. Even so, experiments have shown that the introduction of stowage in ice would effect a substantial improvement on current practice.

Changes in fish after death are brought about by bacteria and enzymes, the activities of which are reduced by lowering the temperature. Stowage in ice, provided plenty is always present, keeps fish chilled at a temperature of about $0^{\circ}$ to $1^{\circ} \mathrm{C}$. $\left(32^{\circ}\right.$ to $33.8^{\circ} \mathrm{F}$.), at which, however, bacterial spoilage still ensues quite rapidly, autolytic changes playing apparently only a minor part. The unpleasant, characteristic odour of stale fish is not due only to the bacterial breakdown of protein, although this process does occur in the advanced stages of spoilage, ammonia, hydrogen sulphide and indol being split off. In marine fishes some of the unpleasant odour is due to the breakdown of trimethylamine oxide, which is reduced by bacteria to trimethylamine. In elasmobranchs, e.g., skates and dogfish, the flesh contains 1 to 2 per cent. of urea, which is easily broken down to increase the amount of ammonia produced. Freshwater fish, which contain at most only traces of trimethylamine oxide, evolve only ammonia in the volatile base fraction.

Although experienced tasters at the Torry Research Station can appreciate the subtle differences between freshly caught haddock and those stowed in ice for two or three days, little appreciable alteration occurs till about the seventh day. During the second phase, 7th to 11 th day, there is a rapid rise in the trimethylamine content; the odour strengthens, the flesh becomes noticeably softer and the appearance vor. 2,1944 ] 
staler. During the third phase, 11 th to 15 th day, there is rapid deteriora. tion in appearance and odour, both now becoming definitely stale, and the ammonia content begins to increase rapidly. After about the 15th day the fish may best be described as becoming putrid, ammonia increasing up to a point, and other protein breakdown products, hydrogen sulphide and indol, being well in evidence (Shewan, 1937).

The above description of events may be taken to hold approximately for all white fish. Until after about one week's stowage in crushed ice, white fish remain in almost as good condition as when caught. After about two weeks' stowage white fish become definitely stale and are as a rule unpalatable to tasters accustomed to freshly caught fish as standard, although not necessarily inedible.

It is impracticable to gut at sea such small fish as herrings, and the retention of viscera, particularly in feeding fish, renders the herring particularly prone to deterioration. Moreover the oil in the flesh of the herring loses sweetness rapidly. While a gutted haddock will remain in quite good condition for about a day at a temperature of $15^{\circ} \mathrm{C} .\left(59^{\circ} \mathrm{F}\right.$.) but will be definitely distasteful after two days, the corresponding times for ungutted herring are of the order of half a day and $1 \frac{1}{2}$ days (Reay, 1942).

As already remarked, herrings are not as a rule iced at sea, but herrings so treated with plenty of ice remain in a condition almost as good as fresh for about 3 days, and for about 1 week in a condition not regarded as definitely stale.

It is worth remark that fish is obviously more perishable than meat, which can be kept in good condition for something over a month by chilling. Little or nothing appears to be known of any possible loss of the nutritive value of fish during stowage in ice.

The unpalatable substances in stale fish survive cooking. Frying in fat, however, is, amongst simple methods of preparation, as effective as any in masking stale flavours.

\section{Freezing and Cold Storage}

The distance of the more prolific fishing grounds, increasingly being fished in normal times, renders it inevitable that a considerable proportion of iced white fish, when landed in Britain, can justly be described as stale, in the third spoilage phase, as described above. From time to time iced fish is condemned even at landing as being unfit for human consumption. The remedy is to freeze and cold store fish properly at sea on board the catching vessel or a factory ship, or on land situated reasonably close to the fishing grounds. Such cold storage according to the best modern principles can be continued satisfactorily on shore for a period of months, ensuring supplies of any species at any time in a condition almost as good as when freshly caught.

Herrings are to be caught in good, fatty condition and in quantity for little more than six months in the year (Lovern and Wood, 1937) but proper freezing and cold storage can serve to distribute the oatch throughout the whole year.

Smoke cured white fish and kippers also can be successfully cold stored for a period of months.

Bacterial and mould action is effectively inhibited at $-10^{\circ} \mathrm{C} .\left(14^{\circ} \mathrm{F}.\right)$. At this temperature, however, enzymic and physical changes occur at a 
rate which comparatively soon effects undesirable changes in the odour, flavour, texture and appearance of the fish. These changes, which can all be satisfactorily controlled by lowering the temperature of storage sufficiently, may be briefly described.

In white fish and to a somewhat less noticeable extent in fatty fish such as herring, the flesh at the higher temperatures of storage around $-10^{\circ} \mathrm{C}$. $\left(14^{\circ} \mathrm{F}\right.$.) loses its original gelatinous consistency, becoming less viscous and elastic and more fibrous. At the same time the amount of easily expressible fluid increases markedly, so that it is impossible to cut or fillet the thawed fish without losing juice, leaving the flesh drier in consequence. Palatability is impaired, the texture appears to be more crumbly, and the easy exudation of fluid upon first chewing gives the impression first, of "sloppiness," and later of dryness. The effect on the solubility of the muscle proteins is shown in Table 1. The treatment was in this case prolonged, 8 months' storage at $-3^{\circ} \mathrm{C} .\left(26 \cdot 6^{\circ} \mathrm{F}\right.$.) (Reay and Küchel, 1936).

An odd, characteristic flavour that develops in frozen white fish is usually referred to simply as a cold storage flavour and resembles somewhat a mild "salt fishy" flavour. This develops more rapidly in the presence of salt, and may be associated with enzymic changes in the small quantity of fat present (Labrie, 1934) which amounts in cod and haddock to less than 1 per cent. (Reay, Cutting and Shewan, 1943).

In fatty fish, such as herrings, which contain up to 20 per cent. or more of fat (Lovern and Wood, 1937), the oil develops a rancid flavour, the simultaneous production of fat peroxides being used as a method of estimating rancidity (Banks, 1935, 1936, 1937, 1, 2, 1938, 1, 2, 3, 1939). A small degree of rancidity is sometimes regarded as not unpleasant, but when advanced, rancidity can be very distasteful. Development of rancidity, an enzymic process, is accelerated by addition of salt and this is probably one reason why kippers tend to go rancid in cold store sooner than herrings.

TABLE 1

Protein Fractions of Fresh and Frozen Haddock Muscle, Per Cent.

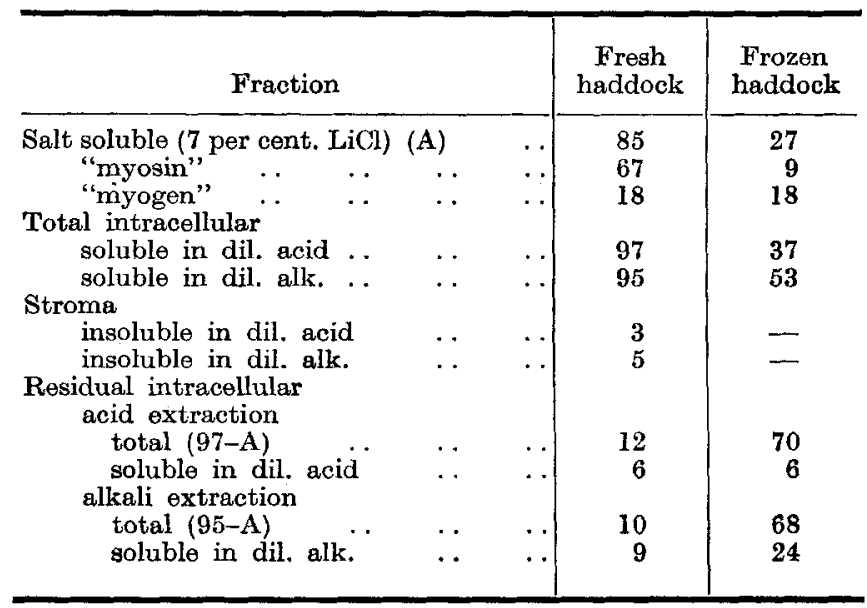


The surface of fatty fish and even of only moderately fatty species such as lemon sole, plaice and halibut, becomes spotted, particularly around the bases of the fins and at cut surfaces, with a rusty coloured, gummy substance. This "rust" is also a product of fat decomposition, and has a repulsive "sweaty" odour and flavour (Reay, 1940). In addition to all these changes, water is continuously evaporating from the surface of the frozen fish (Cutting and Hardy, 1941). In time, toughened, wrinkled patches appear on the surface, an effect known to the trade as "freezer burn." Drying also extends to the interior, so that texture becomes loose, inelastic and spongy, in addition to being tough and dry on the surface, even after cooking. Superficial drying also accelerates the action of the catalytic system responsible for promoting rancidity (Banks, 1938, 1, 2, 3). Loss of moisture by evaporation may be prevented by using moisture proof wrappers or by "glazing" the fish with a covering of ice, and, in common with all the other undesirable changes described, is inhibited markedly by lowering the temperature of storage.

The general effect on storage life is shown in Table 2, as judged mainly by palatability. It must be emphasized that although a limit of palatability is indicated in the table this is not so precisely to be determined as for iced fish. There is here no bacterial spoilage in progress leading rapidly to inedibility. It should also be made clear that the figures in the table apply only to fish frozen when in the freshest condition. Moreover, the figures apply only to fish frozen with satisfactory rapidity.

The more slowly fish are cooled in freezing, the greater the disorganization of the flesh through ice formation, since crystals become fewer and larger, and this eventually affects palatability adversely. To be satisfactorily frozen, fish must cool through the interval $0^{\circ}$ to $-5^{\circ} \mathrm{C} .\left(32^{\circ}\right.$ to $23^{\circ} \mathrm{F}$.) in less than about 3 hours. There is a variety of ways in which the modern refrigerating engineer can arrange for this. Smoke cured fish apparently can tolerate much slower rates of freezing without loss of palatability. The figures in Table 2 refer to cured fish frozen in 1 stone boxes, freezing taking the best part of a day.

TABLE 2

Storage Life of Cold Stored Fish*

\begin{tabular}{|c|c|c|c|}
\hline Type of fish & $\frac{-10^{\circ} \mathrm{C}}{14^{\circ} \overline{\mathrm{F}}}$ & $\frac{-20^{\circ} \mathrm{C}}{-4^{\circ} \mathrm{F}}$ & $\frac{-30^{\circ} \mathrm{C}}{-22^{\circ} \mathrm{F}}$ \\
\hline White fish (gutted) & 1 month & 4 months & 8 months \\
\hline Herrings (ungutted) & (3 to 4 months) & (1 to $1 \frac{1}{2}$ years) & (>4 years) \\
\hline & (2 to 3 months) & (5 to 6 months) & 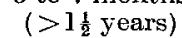 \\
\hline Smoke cured white fish. & 1 month & 3 to 4 months & 6 to 8 month \\
\hline Kippers .. . . & $\begin{array}{l}2 \text { to } 3 \text { weeks } \\
\text { (2 months) }\end{array}$ & $\begin{array}{l}2 \text { months } \\
\text { (5 months) }\end{array}$ & $\begin{array}{l}4 \text { to } 5 \text { month } \\
\text { (>3 years) }\end{array}$ \\
\hline
\end{tabular}

* The unbracketed figures indicate approximately the period at the end of which the fish is still almost as good as fresh or freshly smoked. The bracketed figures indicate approximately the period at the end of which the article has become unpalatable to tasters accustomed to the fresh as standard. 
It is clear from the table that, with regard to temperature of storage, the rule is, the lower the better; and also that the temperature must be much lower than the still fairly customary one of $-10^{\circ} \mathrm{C}$. if really good products are to be available after a few months' storage; storage at temperatures between $-20^{\circ}$ and $-30^{\circ} \mathrm{C}$. $\left(-4^{\circ}\right.$ and $-22^{\circ} \mathrm{F}$.) would meet most needs.

Given fish that have been frozen and stored under the best conditions, the rate at which the fish is thawed has not, within wide limits, any really significant effect upon palatability, although usually there is some loss of juice containing a few per cent. of protein as well as, presumably, some minerals and flavouring bodies. Such losses may be prevented, wherever practicable, by cooking the fish in the frozen state, which, experiment has shown, results in an excellent product (Cutting, 1940).

To all intents and purposes properly frozen fish can be cooked or otherwise processed in the same ways as fresh fish. For example, excellent smoke cures, "finnans" and kippers, and canned herrings, can be obtained from the thawed fish.

A few years ago the Medical Research Council, considering the general question of the effect of modern methods of storing food upon its nutritive value, stated that relatively little loss of known constituents occurs (Department of Scientific and Industrial Research, 1938). This may be taken to cover modern freezing and cold storage.

\section{Dehydration}

Dehydration is a cumbersome term and will not be consistently used here, but it does serve to distinguish the new process of drying from more primitive, traditional procedures, from which it is differentiated by three characteristics. Firstly, dehydrated fish is very dry, containing less than 10 per cent. of water, while dried salted cod for example still contains 40 per cent., the respective percentage losses of water being 98 and 80 . Secondly, drying is much more rapid and proceeds under conditions of scientific control, so that the flavour and texture of the original fish are retained to a much greater degree, without the development of peculiar flavours due to the action of micro-organisms and enzymes. Thirdly, dehydrated fish is already cooked and can be quickly prepared for eating merely by adding the appropriate quantity of water, while dried salted cod for example not only requires to be cooked, but can be cooked only after preliminary soaking to remove salt and "cured" flavours to a point at which the material becomes palatable.

In comparison with freezing, dehydration does not yield a product that can thereafter be treated in every respect in the same way as fresh fish. Since at present fish can be dehydrated successfully only in the minced, cooked condition, only secondary made up dishes, such as fish cakes and kedgerees can be prepared, but these are very similar to those made from minced, cooked fresh fish.

The method of dehydration developed at the Torry Research Station is briefly to dry the cooked, minced flesh of fish, spread on meshed trays, in a current of warm air under carefully controlled conditions of temperature and humidity (Cutting and Reay, 1944), such that the drying period does not exceed about 4 hours, and the temperature of the fish is within the range $50^{\circ}$ to $70^{\circ} \mathrm{C}$. $\left(122^{\circ}\right.$ to $158^{\circ} \mathrm{F}$.).

voL. 2,1844 ] 
Roller drying on steam heated drums also gives satisfactory results, but drying in steam jacketed cylinders of the types used for manufacturing fish meal for animal feeding produces material that has a scorched colour and flavour and a poor texture.

In preparing dehydrated fish some flavour is probably lost during cooking in the juices that exude and which, together with the steam condensed in the cooking retort, are at present discarded for technical reasons. Moreover, the draught of warm air blowing over the fish for 4 hours removes volatile components that contribute to the characteristic flavour of fresh fish. Gadoids, e.g., cod, haddock, whiting, taste much the same when dehydrated, but it is often difficult to differentiate these species in fish cakes made from the fresh fish. Hake is an exception among the gadoids, its characteristic soft texture, and peculiar flavour persisting. The flat fishes, such as lemon soles and plaice, still retain in large measure their characteristic flavours. Elasmobranchs contain urea, have a strong ammoniacal aroma, and are not suitable for drying. Dried herring is a product that differs from the original fresh fish in having a strong, oily flavour, that might not be generally acceptable. This objection does not apply to the medium fatty pelagic species, such as mullet, nor to salmon which retains well the characteristic flavour and texture of fresh salmon.

When herring is smoked before cooking and drying, a very palatable dried kipper is obtained, although the smoky flavour is not quite the same as that of a typical kipper. On the other hand dried smoked white fish has the typical finnan flavour and is an excellent product.

In reconstituting dried fish for incorporation into various dishes, approximately the same amount of water is taken up by the dried material as was lost in the drying, so that the water content rises again nearly to that of the cooked fish, which is of course lower than that of the original fresh fish. For example, fresh haddock flesh usually contains about $4 \cdot 3 \mathrm{~g}$. water per g. of solids; the cooked and reconstituted dried flesh contain ahout 2.7 and $2.5 \mathrm{~g}$. water per g. of solids, respectively.

As in frozen fish, the oil present in dried fatty fish causes these to store less well than dried white fish. Experiments are still in progress, but it may be said provisionally that under temperate conditions the storage life of dehydrated fish in palatable condition is of the order of 12 months, and at tropical temperatures of the order of 6 months, provided the material is stored in tins under nitrogen, that is, gas packed. Dehydrated fatty fish can be compressed into sufficiently compact blocks for almost all the air in a tin to be displaced, in which case gas packing may prove to be less necessary. The addition of smoke tends to mask slight changes in colour and flavour during storage.

The signs of deterioration during storage in air in dehydrated white and fatty fish are first a yellowish brown discolouration and at the same time, a gradual loss of sweet fishy flavour in the reconstituted fish. Later, a flavour begins to develop that is suggestive more of meat extract than of fish and is at the same time rather bitter, and the pieces of mince become noticeably tougher. As the figures given for storage life indicate, storage changes apparently have a fairly high temperature coefficient. Although deterioration is inhibited by gas packing, it is not completely prevented, so that oxidation may not be the only factor concerned, unless 
it can be brought about by the small amounts of oxygen that remain even in gas packed material. Until towards the end of the periods of storage mentioned, none of these changes is really unpleasant and they are scarcely detected by most people in the final fish cake.

Dehydrated fish consists almost only of the fatty and solid matter of the edible portion of the fresh fish. This amounts in cod to about one-thirteenth of the landed or gutted weight. In herrings containing 10 per cent. of fat, it amounts to about one-seventh of the landed or ungutted weight. Moreover, the dehydrated fish can be satisfactorily compressed to afford a very high concentration of protein, fat, and calories per unit of space.

When certain reasonable assumptions are made with regard to type of package, frozen whole cod or frozen cod fillets involve the carriage, respectively, of about 14 and 5 times the weight that the compressed dehydrated fish would have on an equivalent food basis. The corresponding figures for space ocoupied by the frozen fish are 25 and 8 . The comparable factor for weight carried and volume occupied for dried, salted cod is about 3 .

The factors are about 5 for canned herrings, and about 6 for salt cured herrings.

As far as the proximate principles are concerned, there are as yet no clear data concerning loss of nutritive value in fish brought about by the new process of dehydration.

\section{Canning}

Finally, although it has not been a subject of research at the Torry Research Station and cannot therefore be authoritatively discussed, it should be remembered that the canning of fish is a most successful long term method of preservation, competing, in this respect, with freezing and cold storage. As far as can be seen at present, dehydration will not, on the whole, afford such long term preservation as either of these two methods, but should have application when weight carried and space occupied are of special importance. Canning has the special advantage of affording certain long term preservation without further attention after processing, while freezing and cold storage demand proper refrigeration right up to the point of consumption.

Certain kinds of canned fish, particularly oily "packs," like sardines and herrings, are known to have kept well for ten years. Where acid is present, as in herring and tomato sauce, the storage life is shorter, say, five years at most, owing to perforation of the lacquer lining, and resulting corrosion of the tin plate.

The canned product often differs very considerably from the original fresh fish. The heat treatment involved in satisfactory sterilization, "ripening" in the can, and the addition of condiments and oil may all bring about changes in texture and flavour, the products in some instances being preferred by some consumers to the fresh article.

As regards the proximate principles, the previously quoted statement of the Medical Research Council (Department of Scientific and Industrial Research, 1938) can be taken to be applicable.

This paper, largely based on work carried out as part of the programme vox. 2, 1944] 
of the Food Investigation Board, is published by permission of the Department of Scientific and Industrial Research.

\section{REFERENCES}

Banks, A. (1935). Rep. Food Invest, Bd, Lond., 77.

Banks, A. (1936). Rep. Food Invest. Bd, Lond., 101; 104.

Banks, A. (1937, 1). Rep. Food Invest. Bd, Lond., 73; 81.

Banks, A. (1937, 2). J. Soc. chem. Ind., Lond., 56, $13 \mathrm{~T}$.

Banks, A. (1938, 1). Rep. Food Invest. Bd, Lond., 95; $96 ; 106$.

Banks, A. (1938, 2). .J. Soc. chem. Ind., Lond., 57, 124.

Banks, A. (1938, 3). Food Manuf. 13, 88.

Banks, A. (1939). Food Manuf. 14, 83.

Cutting, C. L. (1940). Mod. Refrig. 43, 198.

Cutting, C. L. and Hardy, J. K. (1941). Proc. Brit. Ass. Refrig. 37, 245.

Cutting, C. L. and Reay, G. A. (1944). Proc. Nutr. Soc. 1, 123.

Department of Scientific and Industrial Research (1938). Rep. Food Invest. Bd, Lond., 1937, 3.

Labrie, A. (1934). Rep. Food Invest. Bd, Lond., 101.

Lovern, J. A. and Wood, H. (1937). J. Mar. biol. Ass. U.K. 22, 281.

Reay, G. A. (1940). Mod. Refrig. 43, 142.

Reay, G. A. (1942). Chem. and Ind. 61, 281.

Reay, G. A., Cutting, C. L. and Shewan, J. M. (1943). J. Soc. chem. Ind., Lond., $62,77$.

Reay, G. A. and Küchel, C. C. (1936). Rep. Food Invest. Bd, Lond., 93.

Shewan, J. M. (1937). Rep. Food Invest. Bd, Lond., 75.

Shewan, J. M. (1938). Rep. Food Invest. Bd, Lond., 79.

Shewan, J. M. (1944). Proc. Nutr. Soc. $2,104$. 